\title{
Global teledermatology
}

\author{
Rebecca Gaffney* and Babar Rao \\ Rutgers Robert Wood Johnson Medical School, USA
}

\section{Introduction}

Telemedicine is the delivery of health care services between two remote locations through information and communication technologies to improve a patient's health condition. It is a tool to increase access to quality care services for patients in both developing and developed countries in any situation in which there is a barrier to receiving treatment [1]. There are generally two methods of telemedicine delivery: store-and-forward and live-interactive. The store-and-forward modality involves the transfer of digital images with relevant patient information through email or a web-based platform to a specialist in a remote location for consultation. In liveinteractive telemedicine, the patient and/or their healthcare provider meet with the consulting specialist and interact in real time through videoconferencing. Since its inception about 40 years ago in US hospitals, telemedicine services have expanded across the world and now include many different specialties $[2,3]$.

Dermatology is particularly well suited for telemedicine because it is a visual specialty. Teledermatology, defined as the remote delivery of dermatological services and clinical information using telecommunications technology, is the second most developed telemedicine service area globally, behind teleradiology $[1,4]$. Teledermatology is a rapidly growing field due to technological advancements and its potential to address the shortage of dermatologists in rural and underserved communities. The most recent data published on physician needs assessment estimates that the ideal ratio of dermatologist to population ratio is $1: 30,000$ [5]. This need is largely unmet across the globe, as the International Foundation for dermatology estimates that 3 billion people in 345 developing countries lack basic care for skin diseases [6]. Table 1 demonstrates the disparity in dermatologists around the world [7].

Much of the current literature on teledermatology solely addresses its validity in healthcare delivery, evaluating diagnostic accuracy, reliability, and patient satisfaction in multiple short-term studies. However, there are few published works on established programs, pilot projects, or feasibility studies in teledermatology, which would indicate that a country has an existing infrastructure and technology that can develop into a permanent program. To the best of our knowledge, the prevalence and locations of teledermatology programs have not been assessed globally. The objective of this paper is to identify established and pilot teledermatology programs across the world.

\section{Methods}

This study looked at the 194 member states recognized by the World Health Organization. We searched the PubMed MEDLINE [in All Fields] and Scopus databases [in Article title, Abstract, and Keywords] for teledermatology programs in each country from 1995 to present. In our search, we used the terms "teledermatology AND [country]" and "telemedicine OR telehealth AND dermatology AND [country]". Only articles in English with titles and abstracts that were published online and in print were considered for inclusion. Search results were then screened and studies were excluded based on title and/or abstract if the study solely measured outcomes of diagnostic reliability and accuracy of teledermatology vs. face-to-face consultation, patient satisfaction with the program, or cost-benefit analysis. All articles with descriptive studies of established programs, pilot studies, and feasibility studies were reviewed. The reference lists of identified studies were also searched for further relevant studies.

\section{Results}

Of the 194 countries searched in the literature, 81 were found to have an established teledermatology program, a telemedicine program that includes dermatology, a pilot project in teledermatology, or a feasibility study in teledermatology. The study found 153 total programs globally. Among both active and non-active teledermatology programs, a majority ( $86 \%$ ) of programs used store-and-forward as the method of delivery. The remainder of programs used live-interactive, a combination, or an unknown method of delivery.

There was a total of 133 sustained teledermatology programs or active pilot projects around the globe (Figure 1). These programs

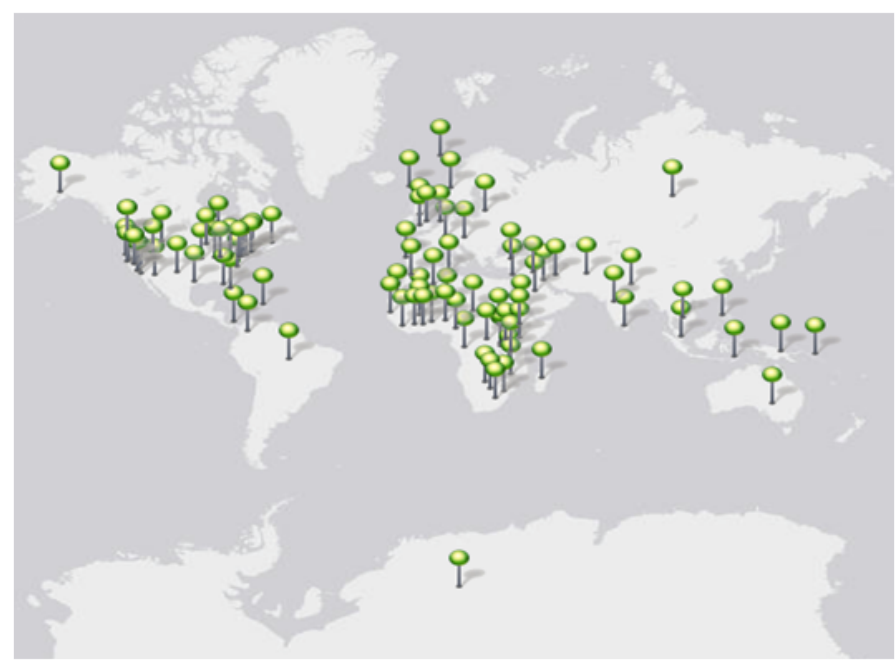

Figure 1. Map of sustained teledermatology programs and active pilot programs $* 4$ pilot programs are no longer active [8-40].

Correspondence to: Rebecca Gaffney, Rutgers Robert Wood Johnson Medical School Class, USA, E-mail: rgg49@rwjms.rutgers.edu

Received: September 06, 2015; Accepted: October 12, 2015; Published: October 15,2015 
include store-and-forward and live-interactive modalities delivered through government national health systems and other government initiatives, commercial organizations for consumers, and nonprofit/charitable organizations. In addition, military use of ongoing teledermatology programs was also found in the literature review and included in this paper.

17 countries performed feasibility or pilot studies, indicating the presence of technology and teledermatology infrastructure which is presented below (Table 2).

Of 131 countries searched in the study that did not have mention of a teledermatology program, a majority $(80 \%)$ were in the bottom third in terms of population rank [60]

Teledermatology programs in developing countries were mainly delivered through non-profit/charitable humanitarian health networks with volunteer physicians and a simple, web based platform or email for communication between the consultee and specialist (Table 3 ).

\section{Discussion}

According to a 2011 WHO survey on global telemedicine, teledermatology is more established in high-income group countries, where the main challenges include legal issues with patient privacy and confidentiality, limited reimbursement for practitioners, and competing health system priorities. Developing countries are more likely to face larger barriers to implementation such as resource issues, high costs, underdeveloped infrastructure, and lack of technical expertise [1]. Therefore, teledermatology has been adopted more for use in the developed world where it is seen as a cost-effective way to increase access to care for patients who cannot travel or have inadequate insurance [63]. However, it has great potential to address challenges faced to those in the developing world that are deprived of even basic health care access.

Although developing countries with a high burden of disease and limited resources or access to specialists can arguably benefit the most from teledermatology, many of these countries lack a reliable power supply and cannot afford any sophisticated software needed for a telemedicine exchange. Physicians and government health policy makers in these regions that have very little to spend on healthcare per person may doubt the need for expensive teledermatology equipment when that money could go to much needed drugs for skin diseases. Additionally, with the exception of leprosy and other infectious diseases that affect the skin, dermatologic conditions are given little importance in developing regions that suffer from major lethal health conditions such as malaria, tuberculosis, and HIV/AIDS [30].

Table 1. Dermatologist-population ratio in different regions of the world.

\begin{tabular}{|l|c|}
\hline USA & $1: 30,000$ \\
\hline UK & $1: 200,000$ \\
\hline Other European Countries & $1: 50,000$ \\
\hline Asia & $1: 2000,000$ (Urban) \\
\hline & $1: 780,000$ (rural) \\
\hline Sub-Sahara countries & $1: 1,000,000$ (urban) \\
\hline & $1: 5-50$ million (rural) \\
\hline Central/South America & $1: 76,000$ (urban) \\
\hline & $1: 1-66$ million (rural) \\
\hline
\end{tabular}

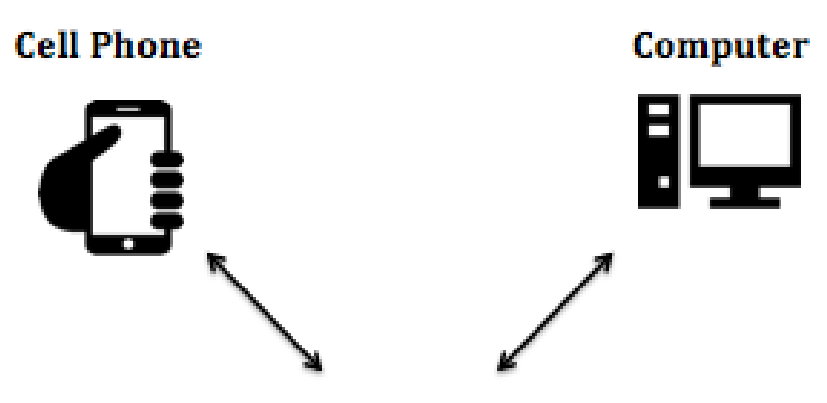

Web Based Platform
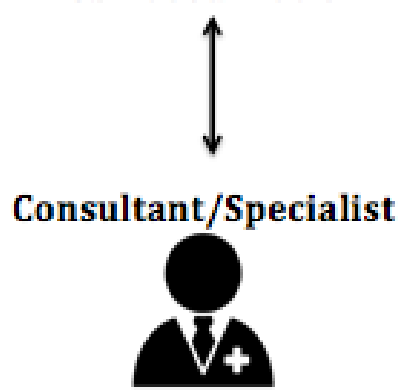

Figure 2. Flow of Information for Swinfen Charitable Trust, Telederm, and iPath Telehealth Networks.

Recognizing this dilemma faced by developing countries, humanitarian health networks have developed easy-to-use, open access platforms for underserved regions around the world. The only requirements for participation in the teledermatology programs are access to the internet and a device to send and upload pictures (digital camera or phone). Figure 2 shows a simple schematic of the information exchange in these health network teledermatology programs.

These telehealth networks have been proven to be an efficient method of consultation. A prospective review of email consultations between referring doctors and consulting specialists of Swinfen Charitable Trust operations showed a median time of 1.5 days from a referral to a definitive reply. A similar study conducted on Telederm showed that $60 \%$ of requests were answered within one day, $35 \%$ within one week, and $4 \%$ in two weeks during the first two years of operation. Because the only requirements for participation in the teledermatology programs are access to the internet and a device to send and upload pictures (digital camera or phone), these teledermatology programs have been able to penetrate many developing countries. From 2000 to 2015, internet usage in underdeveloped regions such as Africa, Latin America, and the Middle East have exceptionally grown (Table 4) [64]. Additionally, access to mobile services in the developing world has outpaced the rate at which much of the population is gaining access to basic services such as banking, sanitation, and electricity [65]. With internet and mobile phone usage becoming increasingly available in all areas of the world, these telehealth networks have the potential to expand to more developing countries.

This review was done to provide a comprehensive overview of the prevalence and locations of teledermatology programs globally and has some limitations. New teledermatology programs and pilot projects without published data could exist and were not included in this paper. Articles published in different languages were not reviewed which could possibly explain the lack of teledermatology programs found in 
Table 2. Summary of studies on teledermatology programs.

\begin{tabular}{|c|c|c|c|c|c|}
\hline Study & Country & Name and Location of Consulting Institution & $\begin{array}{l}\text { Geographical } \\
\text { Location(s) and/or } \\
\text { Institution of Patient } \\
\text { Recruitment }\end{array}$ & $\begin{array}{l}\text { Modality and Relevant } \\
\text { Technology }\end{array}$ & Comments \\
\hline [41] & Argentina & Universidad Nacional de Tucuman & $\begin{array}{l}\text { Ranchillos, Tucumán } \\
\text { (province) }\end{array}$ & $\begin{array}{l}\text { SAF using the Telemedicine in } \\
\text { the Provincial System of Health } \\
\text { (SIPROSA) }\end{array}$ & \\
\hline [42] & Belgium & $\begin{array}{l}\text { Partnership between } \\
\text { Department of Dermatology, } \\
\text { HôpitalUniversitaireErasme, UniversitéLibre de } \\
\text { Bruxelles, Belgium and Dermatology Department } \\
\text { of Kaolack Hospital in Senegal, West Africa; }\end{array}$ & $\begin{array}{l}\text { Available to all } \\
\text { internet users }\end{array}$ & $\begin{array}{l}\text { Open source free website for } \\
\text { telediagnosis, education, and } \\
\text { information }\end{array}$ & $\begin{array}{l}\text { Website titled "Black Skin } \\
\text { Dermatology Online", intended } \\
\text { for use of consult for patients with } \\
\text { dark pigmented skin. Currently no } \\
\text { telediagnosis on website }\end{array}$ \\
\hline [43] & Chile & $\begin{array}{l}\text { Consultation to a specialist in Santiago, Chile } \\
\end{array}$ & $\begin{array}{l}\text { Rural communities in } \\
\text { Melipilla, Talagante, } \\
\text { Isla de Maipo, } \\
\text { Curacaví, and María } \\
\text { Pinto, Chile }\end{array}$ & $\begin{array}{l}\text { SAF using Ministry of Health } \\
\text { (MINSAL) TD electronic } \\
\text { platform }\end{array}$ & \\
\hline [44] & Denmark & $\begin{array}{l}\text { Department of Dermatology, Roskilde Hospital, } \\
\text { Roskilde, Denmark }\end{array}$ & $\begin{array}{l}4 \text { home-care } \\
\text { organizations in } \\
\text { eastern Denmark }\end{array}$ & $\begin{array}{l}\text { SAF using Plejenet, a web-based } \\
\text { program created by Dansk } \\
\text { Telemedicin }\end{array}$ & Specifically looked at wound care \\
\hline [45] & Egypt & $\begin{array}{l}\text { Department of Dermatology, Al Hussein } \\
\text { University Hospital of Al-Azhar University in } \\
\text { Cairo, Egypt }\end{array}$ & $\begin{array}{l}\text { Cairo, Egypt; Al } \\
\text { Hussein University } \\
\text { Hospital of Al-Azhar } \\
\text { University }\end{array}$ & $\begin{array}{l}\text { SAF on a mobile phone with } \\
\text { ClickDoc (Click Diagnostics, } \\
\text { Boston, MA) software and the } \\
\text { telederm.org web-based platform }\end{array}$ & \\
\hline [46] & Finland & $\begin{array}{l}\text { Department of Dermatology, Tampere University } \\
\text { Hospital in Tampere, Finland }\end{array}$ & $\begin{array}{l}\text { Ikaalinen, Finland; } \\
\text { Primary Health Care } \\
\text { Centre in Ikaalinen }\end{array}$ & $\begin{array}{l}\text { Live-interactive } \\
\text { videoconferencing }\end{array}$ & \\
\hline [47] & Germany & $\begin{array}{l}\text { Clinic for Skin Diseases of the University of } \\
\text { Greifswald, Greifswald, Germany }\end{array}$ & & $\begin{array}{l}\text { SAF on a smart phone and an } \\
\text { online web-based portal }\end{array}$ & $\begin{array}{l}\text { Information was transmitted directly } \\
\text { via patients }\end{array}$ \\
\hline [48] & Greece & $\begin{array}{l}\text { Department of Dermatology and Plastic Surgery } \\
\text { in the Athens General Hospital }\end{array}$ & & SAF & \\
\hline [49] & Guatemala & $\begin{array}{l}\text { Division of Dermatology, Albert Einstein } \\
\text { College of Medicine, Bronx, NY, USA }\end{array}$ & $\begin{array}{l}\text { Lake Atitlán, } \\
\text { Guatemala; Rural } \\
\text { clinics }\end{array}$ & $\begin{array}{l}\text { SAF on a smart phone with } \\
\text { an application developed by } \\
\text { ClickMedix (mobile application/ } \\
\text { encrypted website) }\end{array}$ & $\begin{array}{l}\text { medical students served as in-country } \\
\text { proxies acting as liaisons between the } \\
\text { in-country provider team and remote } \\
\text { teledermatologist }\end{array}$ \\
\hline [50] & Jordan & Prince Hamzah Hospital in Amman, Jordan & $\begin{array}{l}\text { Mafraq Government } \\
\text { Hospital and Queen } \\
\text { Rania Hospital in } \\
\text { Jordan }\end{array}$ & $\begin{array}{l}\text { Live-interactive } \\
\text { videoconferencing }\end{array}$ & \\
\hline [51] & Mexico & $\begin{array}{l}\text { Department of Dermatology General Hospital of } \\
\text { Mexico in Mexico City }\end{array}$ & $\begin{array}{l}\text { Rural clinic in a small } \\
\text { island }\end{array}$ & $\begin{array}{l}\text { SAF with social media Facebook } \\
\text { used as the web-based platform }\end{array}$ & \\
\hline$[52]$ & Mongolia & $\begin{array}{l}\text { Mongolian National University of Medical } \\
\text { Sciences in Ulaanbaatar, Mongolia. }\end{array}$ & $\begin{array}{l}\text { Districts Dhovd, } \\
\text { Khuvgul, and Bulgan }\end{array}$ & $\begin{array}{l}\text { SAF with mobile phone based, } \\
\text { open source software platform } \\
\text { data uploaded to Open MRS } \\
\text { (electronic record system) }\end{array}$ & \\
\hline$[53]$ & New Zealand & $\begin{array}{l}\text { Department of Dermatology of Health Waikato } \\
\text { in Hamilton }\end{array}$ & $\begin{array}{l}\text { Taumarunui Hospital, } \\
\text { Taupo Health Centre } \\
\text { and the Ranolf Medical } \\
\text { Centre }\end{array}$ & $\begin{array}{l}\text { Live-interactive } \\
\text { videoconferencing }\end{array}$ & $\begin{array}{l}\text { in association with the UK } \\
\text { Multicentre Teledermatology trials }\end{array}$ \\
\hline$[54]$ & Pakistan & $\begin{array}{l}\text { Department of Pakistan Institute of Medical } \\
\text { Sciences in Islamabad, Pakistan }\end{array}$ & $\begin{array}{l}\text { Islamabad, Pakistan; } \\
\text { Department of Pakistan } \\
\text { Institute of Medical } \\
\text { Sciences Institute of } \\
\text { Dermatology King } \\
\text { Edward Medical } \\
\text { College Lahore }\end{array}$ & $\begin{array}{l}\text { SAF using TelmedPak web- } \\
\text { based platform }\end{array}$ & \\
\hline $\begin{array}{l}1-[39] \\
2-[55]\end{array}$ & South Africa & $\begin{array}{l}\text { 1- Telemedicine Unit of the University of } \\
\text { Transkei (UNITRA) in Umtata } \\
\text { 2- Port Shepstone Hospital }\end{array}$ & $\begin{array}{l}\text { 1- Port St. John's, } \\
\text { South Africa } \\
\text { 2- Durban, South } \\
\text { Africa; Nelson R } \\
\text { Mandela School of } \\
\text { Medicine in }\end{array}$ & $\begin{array}{l}\text { 1- SAF using the iPath } \\
\text { application network } \\
\text { 2- Live-interactive } \\
\text { videoconferencing }\end{array}$ & \\
\hline $\begin{array}{l}1-[56] \\
2-[57]\end{array}$ & Spain & & 1- Aragón, Spain & 1-SAF web-based & 2- ongoing \\
\hline $\begin{array}{l}1-[58] \\
2-[59]\end{array}$ & Sweden & $\begin{array}{l}\text { 1\&2-Department of Dermatology at Sahlgrenska } \\
\text { University Hospital }\end{array}$ & $\begin{array}{l}\text { 1-Referred by general } \\
\text { practitioners in } \\
\text { Gothernberg, Sweden } \\
\text { 2-unknown }\end{array}$ & $\begin{array}{l}\text { SAF } \\
1-\text { mms messaging on a mobile } \\
\text { phone } \\
\text { 2- Tele-Dermis and iDoc24 } \\
\text { mobile application }\end{array}$ & \\
\hline
\end{tabular}


Table 3. Humanitarian Telehealth Networks.

\begin{tabular}{|c|c|c|c|}
\hline $\begin{array}{l}\text { Name of } \\
\text { Network }\end{array}$ & Countries Served & Interface Used & Program Information \\
\hline $\begin{array}{l}\text { Swinfen } \\
\text { Charitable Trust }\end{array}$ & $\begin{array}{l}\text { Timor-Leste, Papua New Guinea, } \\
\text { Cambodia, Sri Lanka, Nepal, Iraq, } \\
\text { Afghanistan }\end{array}$ & Email & $\begin{array}{l}\text { Second opinions delivered to doctors in developing } \\
\text { nations via volunteer specialists around the world. } \\
\text { Consults are offered in } 30 \text { different specialties, with } \\
\text { dermatology being one of the most common [61]. }\end{array}$ \\
\hline Telederm & $\begin{array}{l}\text { Africa Telederm Project: } \\
\text { Swaziland, Lesotho, Botswana, } \\
\text { Liberia, Eritrea, Malawi, Burkina Faso, } \\
\text { Mozambique, Uganda, Kenya, Tanzania, } \\
\text { Nigeria }\end{array}$ & $\begin{array}{l}\text { Web based platform: } \\
\text { http://www.telederm.org }\end{array}$ & $\begin{array}{l}\text { Request is sent with relevant clinical information, } \\
\text { and up to } 3 \text { images are uploaded and sent to an } \\
\text { expert. Correspondence is private. Images can also } \\
\text { be sent to an online discussion forum[62]. }\end{array}$ \\
\hline iPath & $\begin{array}{l}\text { Solomon islands, Lithuania, Switzerland } \\
\text { RAFT (Réseau en Afrique Francophone } \\
\text { pour la Télémédecine): } \\
\text { Mauritania, Congo (Brazzaville), Benin, } \\
\text { Burundi, Tunisia, Chad, Senegal, Rwanda, } \\
\text { Mali, Niger, Burkina Faso, Madagascar, } \\
\text { Cameroon, Cote D'Ivoire, Morocco, } \\
\text { Algeria, Congo (Kinshasa) } \\
\text { Medecins Sans Frontiers: } \\
\text { South Sudan, Congo (Kinshasa), Ethiopia }\end{array}$ & $\begin{array}{l}\text { Web based platform: } \\
\text { http://www.openclinical.org/os_iPath.html }\end{array}$ & $\begin{array}{l}\text { Open access telemedicine platform hybrid web } \\
\text { and email application for exchange of medical } \\
\text { knowledge, distance consultations, group } \\
\text { discussions and distance teaching in medicine[39] }\end{array}$ \\
\hline
\end{tabular}

Table 4. World Internet Usage and Population Statistics.

\begin{tabular}{|l|c|c|c|}
\hline World Region & Internet Users 2000 & Internet Users 2015 & Growth 2000-2015 \\
\hline Africa & $4,514,400$ & $318,633,889$ & $3,958.2 \%$ \\
\hline Latin America/Caribbean & $18,068,919$ & $322,422,164$ \\
\hline Middle East & $3,284,800$ & $113,609,510$ \\
\hline
\end{tabular}

non-English speaking regions. Also, because a majority of the countries without a known teledermatology program were the least populous, it is possible that there is not a significant need for dermatologists in these areas.

\section{Conclusion}

In areas that do not have access to dermatologic care due to distance or simple manpower, teledermatology seems like an ideal solution to reach the underserved. However, many factors such as cost, lack of access to modern communication, and underdeveloped infrastructure serve as major obstacles to its widespread use. Teledermatology has been demonstrated to be feasible and diagnostically accurate in many different settings. Although teledermatology programs are more prevalent in developed countries, non-profit/charitable humanitarian health networks have been able to serve many developing regions with a free and an easy-to-use interface. Future efforts need to focus on expanding the outreach of these existing humanitarian telehealth networks and/or simple, inexpensive technology and strategies to sustain programs in developed countries and developing countries that suffer from a high burden of disease with limited resources.

\section{References}

1. http://www.who.int/goe/publications/goe_telemedicine_2010.pdf.

2. http://www.americantelemed.org/about-telemedicine/what-is-telemedicine - .VeXbaEv4vwI.

3. Perednia DA, Brown NA (1995) Teledermatology: one application of telemedicine. Bull Med Libr Assoc 83: 42-47. [Crossref]

4. https://www.aad.org/members/practice-and-advocacy-resource-center/practicearrangements-and-operations/teledermatology.
5. http://www.merritthawkins.com/pdf/a-review-of-physician-to-population-ratios.pdf.

6. http://www.ifd.org/about-ifd/who-we-help.

7. Burns DA (2004) Introduction and historical bibliography, in Rook' Textbook of Dermatology. Oxford: Blackwell Science. 1.1-1.7.

8. Wang $\mathrm{Z}, \mathrm{Gu} \mathrm{H}$ (2009) A review of telemedicine in China. $J$ Telemed Telecare 15: 23-27. [Crossref]

9. https://one.telehealth.ph/beta/2015/01/21/pds-and-nthc-collaborates-trains-newspecialists-for-teledermatology/.

10. Lipoff JB, Cobos G, Kaddu S, Kovarik CL (2015) The Africa teledermatology project: A retrospective case review of 1229 consultations from sub-Saharan Africa. Journal of the American Academy of Dermatology 72: 1084-1085. [Crossref]

11. Shin H, Kim DH, Ryu HH, Yoon SY, Jo SJ (2014) Teledermatology consultation using a smartphone multimedia messaging service for common skin diseases in the Korean army: a clinical evaluation of its diagnostic accuracy. $J$ Telemed Telecare 20: 70-74. [Crossref]

12. Delaigue S, Morand JJ, Olson D, Wootton R, Bonnardot L (2014) Teledermatology in Low-Resource Settings: The MSF Experience with a Multilingual Tele-Expertise Platform. Front Public Health 2: 233. [Crossref]

13. Vega S, Marciscano I, Holcomb M, Erps KA, Major J, et al., (2013) Testing a top-down strategy for establishing a sustainable telemedicine program in a developing country: the Arizona telemedicine program-US Army-Republic of Panama Initiative. Telemed $J$ E Health 19: 746-753. [Crossref]

14. National Telehealth Center, Health workers in cordillera trained on DOH' telemedicine project. 2013.

15. Assis TG, Palhares DM, Alkmim MB, Marcolino MS (2013) Teledermatology for primary care in remote areas in Brazil. J Telemed Telecare 19: 494-495. [Crossref]

16. Weinberg J, Kaddu S, Kovarik C (2012) Teledermatology in Developing Countries, in Telemedicine in Dermatology, Springer Berlin Heidelberg. p. 43-53.

17. Oliveira TC, Branquinho MJ, Gonçalves L (2012) State of the art in telemedicineconcepts, management, monitoring and evaluation of the telemedicine Programme 
in Alentejo (Portugal). Studies in Health Technology and Informatics 179: 29-37. [Crossref]

18. Armstrong AW, Wu J, Kovarik CL, Goldyne ME, Oh DH, et al., (2012) State of teledermatology programs in the United States. J Am Acad Dermatol 67: 939-944. [Crossref]

19. Desai B, McKoy K, Kovarik C (2010) Overview of international teledermatology. Pan Afr Med J 6: 3. [Crossref]

20. Crompton P, Motley R, Morris A (2010) Teledermatology - the Cardiff experience. $J$ Vis Commun Med 33: 153-158. [Crossref]

21. Kaddu S, Soyer HP, Gabler G, Kovarik C (2009) The Africa Teledermatology Project: preliminary experience with a sub-Saharan teledermatology and e-learning program. $J$ Am Acad Dermatol 61: 155-157. [Crossref]

22. Kaddu S, Kovarik C, Gabler G, Soyer PH (2009) Teledermatology in developing countries, in Telehealth in the Developing World. International Development Research Centre: Ottawa, ON. p. 121-134

23. Sánchez C, Triana E, Romero E (2008) A flexible web oriented Telehealth platform using a RIM-HL7 Based Model. in 2008 Euro American Conference on Telematics and Information Systems, EATIS 2008, Aracaju.

24. McManus J, Salinas J, Morton M, Lappan C, Poropatich R (2008) Teleconsultation program for deployed soldiers and healthcare professionals in remote and austere environments. Prehosp Disaster Med 23: 210-216. [Crossref]

25. Jemec GB, Heidenheim M, Dam TN, Vang E (2008) Teledermatology on the Faroe Islands. Int J Dermatol 47: 891-893. [Crossref]

26. Mars M (2007) Telemedicine in KwaZulu-Natal: From failure to cautious optimism. Journal of Telemedicine and Telecare 13: 57-59.

27. See A, Lim AC, Le K, See JA, Shumack SP (2005) Operational teledermatology in Broken Hill, rural Australia. Australas J Dermatol 46: 144-149. [Crossref]

28. Cho JM (2005) TEIN-based teledermatological service system among Korea, China and Austria. in 2005 27th Annual International Conference of the Engineering in Medicine and Biology Society, IEEE-EMBS 2005. Shanghai.

29. Lawton S (2004) Development of a district-wide teledermatology service. Nurs Times 100: $38-41$.

30. Schmid-Grendelmeier P, Doe P, Pakenham-Walsh N (2003) Teledermatology in subSaharan Africa. Curr Probl Dermatol 32: 233-246.

31. Mallett RB (2003) Teledermatology in practice. Clin Exp Dermatol 28: 356-359. [Crossref]

32. Schmid-Grendelmeier P1, Masenga EJ, Haeffner A, Burg G (2000) Teledermatology as a new tool in sub-saharan Africa: an experience from Tanzania. J Am Acad Dermatol 42: 833-835. [Crossref]

33. Bilalovic N, Paties C, Mason A (1998) Benefits of using telemedicine and first results in Bosnia and Herzegovina. J Telemed Telecare 4: 91-93. [Crossref]

34. Valenzuela J, Arguello A, Cendales JG, Rizo CA (2007) Web-based asynchronous teleconsulting for consumers in Colombia: a case study. (1438-8871 (Electronic))

35. Poropatich, R.K., et al., The U.S. Army telemedicine program: general overview and current status in Southwest Asia. J Med Internet Res 9: e33. [Crossref]

36. Klaz I, Wohl Y, Nathansohn N, Yerushalmi N, Sharvit S, et al., (2005) Teledermatology: quality assessment by user satisfaction and clinical efficiency. Isr Med Assoc J 7: 487490. [Crossref]

37. Kaliyadan, F., et al., Mobile teledermatology--patient satisfaction, diagnostic and management concordance, and factors affecting patient refusal to participate in Saudi Arabia. J Telemed Telecare 19: 315-319. [Crossref]

38. Janardhanan L1, Leow YH, Chio MT, Kim Y, Soh CB (2008) Experience with the implementation of a web-based teledermatology system in a nursing home in Singapore. J Telemed Telecare 14: 404-409. [Crossref]

39. Brauchli K1, O'mahony D, Banach L, Oberholzer M (2005) iPath - a Telemedicine Platform to Support Health Providers in Low Resource Settings. Stud Health Technol Inform 114: 11-7. [Crossref]
40. Arican O (2007) E-dermatology: emails about dermatological diseases on the Internet. J Dermatol 34: 375-80. [Crossref]

41. Rotger VI (2011) Teledermatology: An experience in Tucumán. 8th Argentinean Bioengineering Society Conference, SABI 2011 and 7th Clinical Engineering Meeting.

42. Ezzedine K, Amiel A, Vereecken P, Simonart T, Schietse B, et al., (2008) Black Skin Dermatology Online, from the project to the website: a needed collaboration between North and South. J Eur Acad Dermatol Venereol 22:1193-1199. [Crossref]

43. Gatica, JL, Bertoló S, Morales E, Espinoza M, Contreras C (2015) Store-and-forward teledermatogy in Chile: A contribution to primary health care. Piel 30: 148-154.

44. Zarchi K, Haugaard VB, Dufour DN, Jemec GB (2015) Expert advice provided through telemedicine improves healing of chronic wounds: prospective cluster controlled study. J Invest Dermatol 135: 895-900. [Crossref]

45. Tran K, Ayad M, Weinberg J, Cherng A, Chowdhury M, et al., (2011) Mobile teledermatology in the developing world: implications of a feasibility study on 30 Egyptian patients with common skin diseases. J Am Acad Dermatol 64: 302-309. [Crossref]

46. Lamminen H, Tuomi ML, Lamminen J, Uusitalo H (2000) A feasibility study of realtime teledermatology in Finland. J Telemed Telecare 6: 102-107. [Crossref]

47. Berndt RD, Takenga MC, Kuehn S, Preik P, Dubbermann D, et al., (2012) Development of a mobile teledermatology system. Telemed J E Health 18: 668-673. [Crossref]

48. Maglogiannis I (2004) Design and implementation of a calibrated store and forward imaging system for teledermatology. J Med Syst 28: 455-467. [Crossref]

49. Greisman L, Nguyen TM, Mann RE, Baganizi M, Jacobson M, et al. (2015) Feasibility and cost of a medical student proxy-based mobile teledermatology consult service with Kisoro, Uganda, and Lake Atitlan, Guatemala. Int J Dermatol 54: 685-692. [Crossref]

50. Al Quran HA, Khader YS, Ellauzi ZM, Shdaifat A (2015) Effect of real-time teledermatology on diagnosis, treatment and clinical improvement. $J$ Telemed Telecare 21: 93-99. [Crossref]

51. Garcia-Romero MT1, Prado F, Dominguez-Cherit J, Hojyo-Tomomka MT, Arenas R (2011) Teledermatology via a social networking web site: a pilot study between a general hospital and a rural clinic. Telemed J E Health 17: 652-655. [Crossref]

52. Byamba K, Syed-Abdul S, García-Romero M, Huang CW, Nergyi S, et al. Mobile teledermatology for a prompter and more efficient dermatological care in rural Mongolia. Br J Dermatol 173: 265-267. [Crossref]

53. Oakley AMM, Rennie MH (2004) Retrospective review of teledermatology in the Waikato, 1997-2002. Australas J Dermatol 45: 23-28. [Crossref]

54. Rashid E, Ishtiaq O, Gilani S, Zafar A (2003) Comparison of store and forward method of teledermatology with face-to-face consultation. J Ayub Med Coll Abbottabad 15 34-36. [Crossref]

55. Mars M, Dlova N (2008) Teledermatology by videoconference: Experience of a pilot project. South African Family Practice 50: 70-70d.

56. Moreno-Ramirez D, Ferrandiz L, Nieto-Garcia A, Carrasco R, Moreno-Alvarez P, et al. (2007) Store-and-forward teledermatology in skin cancer triage: Experience and evaluation of 2009 teleconsultations. Arch Dermatol 143: 479-484. [Crossref]

57. Lasierra N, Alesanco A, Gilaberte Y, Magallón R, García J (2012) Lessons learned after a three-year store and forward teledermatology experience using internet: Strengths and limitations. Int J Med Inform 81: 332-343. [Crossref]

58. Börve A1, Holst A, Gente-Lidholm A, Molina-Martinez R, Paoli J (2012) Use of the mobile phone multimedia messaging service for teledermatology. $J$ Telemed Telecare 18: 292-296. [Crossref]

59. Börve A1, Terstappen K, Sandberg C, Paoli J (2013) Mobile teledermoscopy-there's an app for that! Dermatol Pract Concept 3:41-48. [Crossref]

60. https://www.census.gov/population/international/data/countryrank/rank.php.

61. Wootton R, Youngberry K, Swinfen P, Swinfen R (2014) Prospective case review of a global e-health system for doctors in developing countries. $J$ Telemed Telecare 10 Suppl 1: 94-6. [Crossref]

62. Massone C, Maak D, Hofmann-Wellenhof R, Soyer HP, Frühauf J (2014) 
Teledermatology for skin cancer prevention: an experience on 690 Austrian patients. $J$ Eur Acad Dermatol Venereol 28: 1103-1108. [Crossref]

63. Houghton V (2015) The full picture: Experts detail the benefits and limitations of teledermatology. Dermatology World 19-23.
64. http://www.internetworldstats.com/stats.htm.

65. https://gsmaintelligence.com/research/?file=130828-scaling-mobile.pdf\&download.

Copyright: $\odot 2015$ Gaffney R. This is an open-access article distributed under the terms of the Creative Commons Attribution License, which permits unrestricted use, distribution, and reproduction in any medium, provided the original author and source are credited. 